\title{
Structural pattern at the northwestern sector of the Tepic-Zacoalco rift and tectonic implications for the Jalisco block, western Mexico
}

\author{
Jaime Urrutia-Fucugauchi ${ }^{1}$ and Tomás González-Morán ${ }^{2}$ \\ ${ }^{1}$ Laboratorio de Paleomagnetismo y Geofisica Nuclear, Universidad Nacional Autonoma de Mexico, Delg. Coyoacan, 04510, D.F., Mexico \\ ${ }^{2}$ Departamento de Recursos Naturales, Instituto de Geofisica, Universidad Nacional Autonoma de Mexico, Delg. Coyoacan, 04510, D.F., Mexico
}

(Received December 19, 2005; Revised May 16, 2006; Accepted May 20, 2006; Online published November 8, 2006)

\begin{abstract}
Analysis of the aeromagnetic anomalies over the northwestern sector of the Tepic-Zacoalco rift documents a NE-SW pattern of lineaments that are perpendicular to the inferred NW-SE boundary between the Jalisco block and the Sierra Madre Occidental. The boundary lies within the central sector of the Tepic-Zacoalco rift immediately north of the Ceboruco and Tepetiltic stratovolcanoes and extends up to the San Juan stratovolcano, where it intersects the NE-SW magnetic anomaly lineament that runs toward the Pacific coast (which intersects two volcanic centers). This $\mathrm{N} 35^{\circ} \mathrm{E}$ lineament separates the central rift zone of low amplitude mainly negative anomalies (except those positive anomalies over the stratovolcanoes) from the zone to the north and west characterized by high amplitude positive long wavelength anomalies. The NE-SW lineament is parallel to the western sector of the Ameca graben and the offshore Bahia de Banderas graben and to the structural features of the Punta Mita peninsula at the Pacific coast, and thus seems to form part of a regional NE-SW pattern oblique to the proposed westward or northwestward motion of the Jalisco block. The orientation of this regional structural pattern at the northern end of the Tepic-Zacoalco rift seems consistent with proposed dominant SW-directed extension along the rift during the Pliocene and Quaternary, rather than with NW-SE lateral strike-slip faulting. The orthogonal pattern that characterizes the northernmost boundary of the Tepic-Zacoalco rift is oblique to the pattern observed in the Grande de Santiago river (which conforms the northern limit of the rift) and for the central-eastern sectors of the Ameca graben (south of the rift). This spatial arrangement of major lineaments and structural elements points to a complex tectonic history for the region that includes the rifting of the Gulf of California and margin deformation due to plate convergence and kinematic re-organization events, and which may have resulted in distinct episodes of left-lateral, right-lateral and normal faulting in Neogene times, as proposed in recent studies.
\end{abstract}

Key words: Tectonics, aeromagnetic anomalies, Tepic-Zacoalco rift, Jalisco block, Mexico.

\section{Introduction}

Geophysical and geological studies of western Mexico have identified the occurrence of several large-scale tectonic features that include a system of rifts delimitating tectonic blocks (Fig. 1). Tectonic evolution in the region has involved major plate reorganizations resulting in the formation of the Rivera and Cocos plates, opening of the Gulf of California and shifting volcanic activity with development of the Trans-Mexican volcanic belt (TMVB). The Jalisco block has been considered a distinct terrane that may have been rifting away from the North American plate since early Pliocene time (Luhr et al., 1985; Allan, 1986; Allan et al., 1991). In this tectonic model, the southeastern boundary of the Jalisco block is marked by the Colima graben, which represents an active continental rift undergoing E-W extension associated with an eastward jump of a segment of the East Pacific rise. The NW-SE TepicZacoalco rift has been considered as the northern boundary of the Jalisco block. Westward (and northwestward) rifting of the block requires various amounts of right-lateral

Copyright (c) The Society of Geomagnetism and Earth, Planetary and Space Sciences (SGEPSS); The Seismological Society of Japan; The Volcanological Society of Japan; The Geodetic Society of Japan; The Japanese Society for Planetary Sciences; TERRAPUB strike-slip faulting along its northern boundary (Luhr et al., 1985; Allan et al., 1991). Recent studies, however, show that the Tepic-Zacoalco graben underwent dominant NE-directed extension during the Pliocene and Quaternary (e.g., Nieto-Obregon et al., 1992; Michaud et al., 1991; Ferrari, 1995; Rosas-Elguera et al., 1996; Rosas-Elguera and Urrutia-Fucugauchi, 1998; Ferrari and Rosas-Elguera, 2000). In this paper we discuss the structural pattern of the northwestern boundary of the Jalisco block as inferred from analysis of the aeromagnetic anomalies and geologic and structural mapping. We show that major structural trends at its northernmost boundary, west of Tepic, are not consistent with recent $\mathrm{W}$ or NW directed motion of the Jalisco block.

\section{Northern Boundary of the Jalisco Block}

Ferrari (1995) and Ferrari and Rosas-Elguera (2000) have documented that the boundary between the Jalisco block and the Sierra Madre Occidental is marked by the northernmost occurrences of the Cretaceous-Paleocene igneous rock assemblage that characterizes the bulk of the Jalisco block (Fig. 2(a)). This assemblage consists mainly of a large granitic-dioritic batholith covered in parts by silicic ash flow tuffs and andesites (affected by low-grade metamorphism) and by marine sediments (Righter et al., 1995). The 


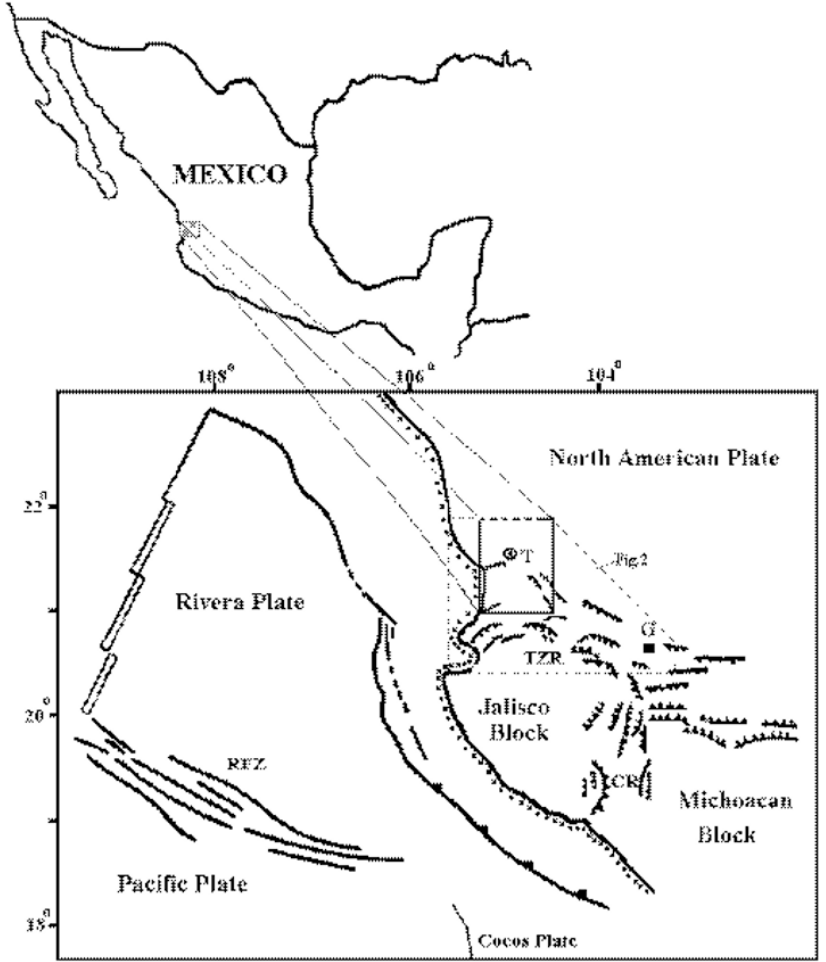

Fig. 1. Schematic map depicting the Jalisco block in western Mexico and the study area in the northern boundary formed by the Tepic-Zacoalco rift. Base map modified from Rosas-Elguera et al. (1993). $\mathrm{G}=$ Guadalajara City, T, Tepic City, TZR=Tepic-Zacoalco rift, $\mathrm{CG}=$ Colima graben, $\mathrm{Ch}=$ Chapala graben, $\mathrm{RFZ}=$ Rivera fracture zone, and $\mathrm{TFZ}=$ Tamayo fracture zone.

Sierra Madre Occidental consists mainly of a Oligocene to early Miocene $1500 \mathrm{~m}$ thick sequence of silicic ash flow tuffs with some andesites and basalts that cover subvolcanic granite-diorite stocks (Gastil et al., 1978; Nieto-Obregon et al., 1985; Moore et al., 1994). Ferrari (1995) proposed that the Jalisco block has been considerably uplifted with respect to the Sierra Madre Occidental, and that the boundary between the two blocks then represents a major deep discontinuity. Geothermal wells drilled by the Federal Commission of Electricity in the area of the Ceboruco volcano, northern sector of Tepic-Zacoalco rift (CB1 and CB2) and in the La Primavera caldera, southern sector of Tepic-Zacoalco rift (PR), document rocks correlative with the Jalisco block (Fig. 2(b)), and Ferrari (1995) has proposed that the boundary lies to the north of the well sites, approximately along the middle of the latest Miocene to Quaternary volcano-sedimentary succession that fills the rift, and through the northern side of the large Tepetiltic, Ceboruco and Tequila stratovolcanoes (Fig. 2(a)).

\section{Shallow Crustal Structure and Aeromagnetic Anomalies}

Regional geophysical studies in western and central Mexico show that the Jalisco block presents a distinct pattern of aeromagnetic and gravity anomalies (Urrutia-Fucugauchi, 1993; Rosas-Elguera et al., 1996; Urrutia-Fucugauchi et al., 1999). High-frequency high-amplitude dipolar anomalies characterize the block in the $3.5 \mathrm{~km}$ upward continued aeromagnetic field. This pattern contrasts sharply with the aero- (a)
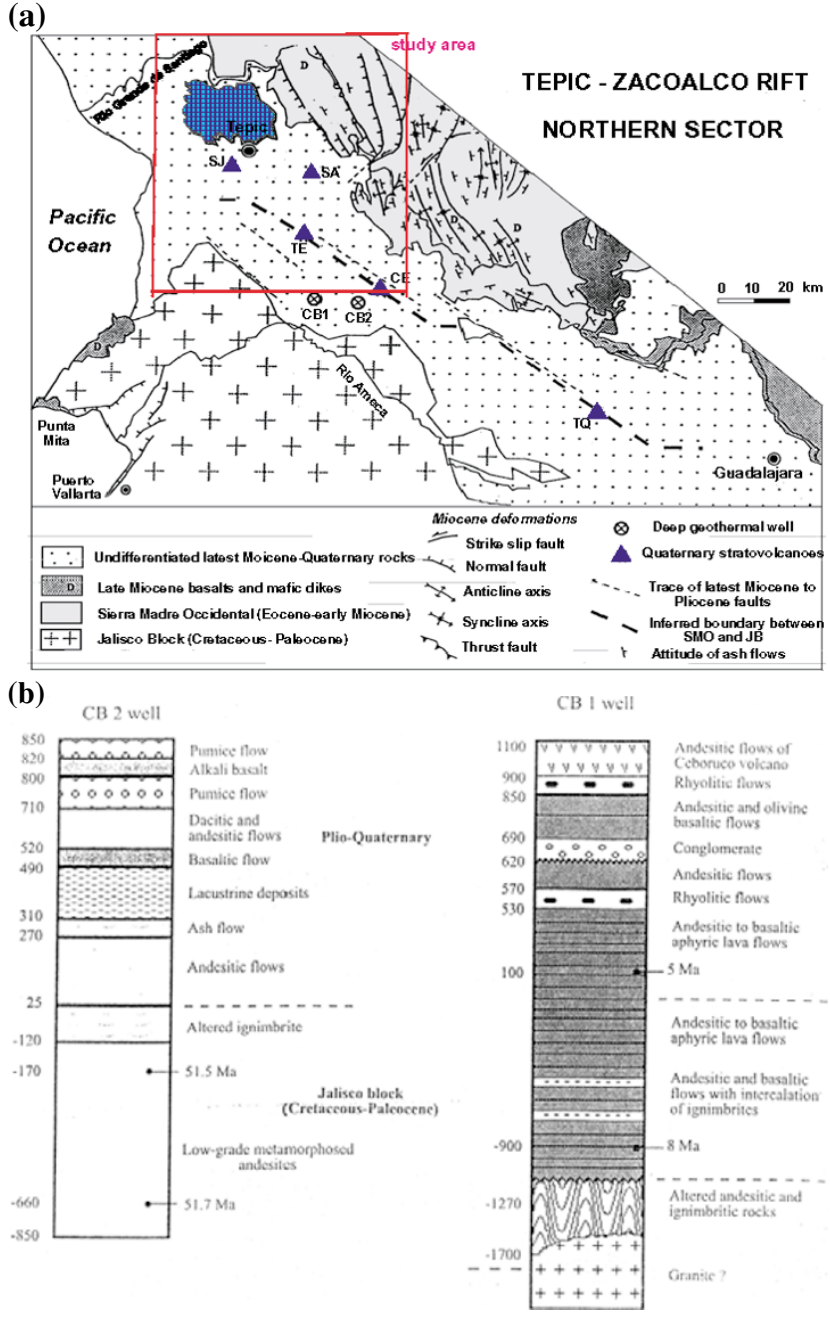

Fig. 2. (a) Schematic geologic map of western Mexico showing the Tepic-Zacoalco rift, the Jalisco block and the Sierra Madre Occidental block (adapted from Ferrari, 1995). The tick dashed line marks the inferred boundary of the Jalisco block. Note that it is not defined west of the San Juan volcano. The triangles indicate major volcanoes (TQ, Tequila; CE, Ceboruco; TE, Tepetiltic; SJ, San Juan; S, Sanganguey; N, Navajas; SP, Cerro Grande San Pedro; T, La Tigra; and C, Ceboruco). Location of geothermal wells drilled by the Federal Comission of Electricity are indicated by o (CB1, Ceboruco-1; CB2, Ceboruco-2; and PR, Primavera). (b) Schematic lithologic columns for the two geothermal wells (adapted from Ferrari and Rosas-Elguera, 2000).

magnetic response of the blocks to the east of the Colima graben and to the north of the Tepic-Zacoalco rift. Thus, the Jalisco block can be distinguished on the basis of its geophysical response. However, the spatial resolution available in the gravity and aeromagnetic data was insufficient for a detailed mapping of the block boundaries (UrrutiaFucugauchi, 1993; Urrutia-Fucugauchi and Molina-Garza, 1992; Rosas-Elguera et al., 1996). More recently, the 'Consejo de Recursos Minerales' (National Mineral Resources Board) has released part of the geophysical information available for the Jalisco and Nayarit areas; in particular the aeromagnetic data at a scale 1:250,000. Details are given elsewhere (Hernandez et al., 1993; T. Gonzalez-Moran, J. Urrutia-Fucugauchi and I. Hernandez, in preparation). The aeromagnetic anomalies (flight survey altitude of 300 meters above ground surface) over the Tepic-Zacoalco rift 

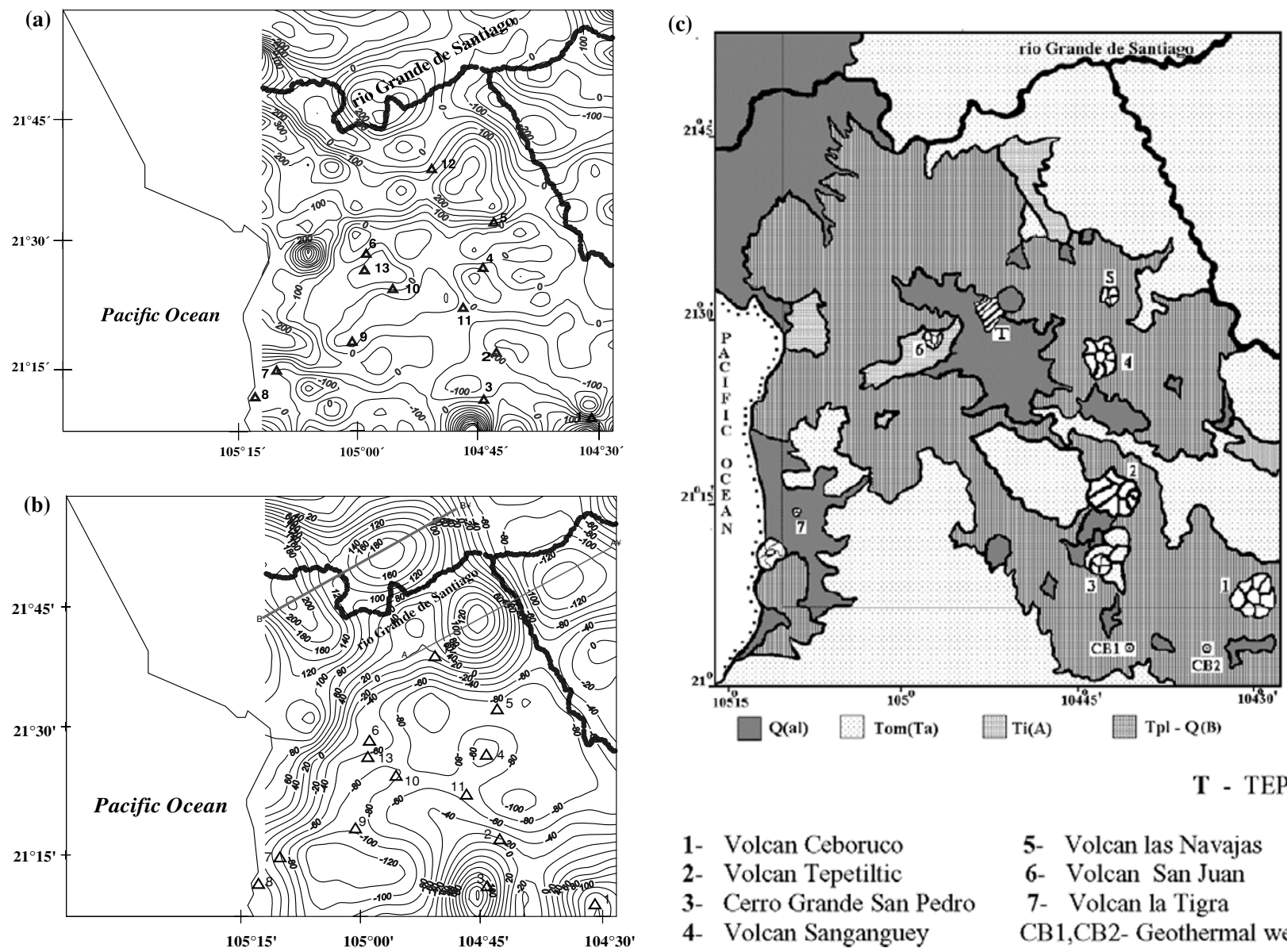

$\begin{array}{ll}\text { 1- } & \text { Volcan Ceboruco } \\ \text { 2- } & \text { Volcan Tepetiltic } \\ \text { 3- } & \text { Cerro Grande San Pedro } \\ \text { 4- } & \text { Volcan Sanganguey }\end{array}$
T - TEPIC
5- Volcan las Navajas
6- Volcan San Juan
7- Volcan la Tigra
CB1,CB2- Geothermal well

Fig. 3. (a) Aeromagnetic anomaly map of northern sector of Tepic-Zacoalco rift. Contour interval is $50 \mathrm{nT}$ (flight survey altitude is $300 \mathrm{~m}$ and lines are spaced every $100 \mathrm{~m}$ and oriented N-S). (b) Reduced to the pole anomaly map and continued upward to a reference level of $5 \mathrm{~km}$. Contour interval is $50 \mathrm{nT}$. The Grande de Santiago river, the location of major volcanic edifices and structural lineaments have been added (see text for interpretation). (c) Schematic map of surface geology showing major lithological units from the INEGI geological map (scale 1:25,000).

and adjacent areas are dominated by high-frequency largeamplitude anomalies that in general correlate well with major volcanic features. Assuming that the boundary between the Jalisco block and the Sierra Madre Occidental is marked by considerable differences in the igneous assemblages, detailed modeling of the aeromagnetic anomalies may assist in delinating the subsurface igneous bodies and in inferring major structural patterns. This analysis will permit to characterize the response associated with the northern Jalisco block boundary, if it is linked closely with a major discontinuity in the depth and composition of the igneous rock assemblages (Figs. 2(a) and (b)).

The region analyzed corresponds to the northernmost sector of the Tepic-Zacoalco rift (Fig. 2(a)) that extends north and west of the Ceboruco volcano to the Pacific coast. It is a rectangular area, approximately from 21 to $22^{\circ} \mathrm{N}$ and between $104^{\circ} 20^{\prime} \mathrm{W}$ and $105^{\circ} 15^{\prime} \mathrm{W}$. The total field aeromagnetic data were obtained with a Geometrics G-803 proton magnetometer at a flight altitude of $300 \mathrm{~m}$ above ground level (contour survey following the topography) and a line spacing of $100 \mathrm{~m}$. Standard correction techniques were applied to the data to produce a $1 \mathrm{~km}$ regularly spaced grid. A regional field calculated from the International Geomagnetic Reference Field (IGRF) was then substracted from the observed field data and the residual field was countoured using a bi-cubic spline algorithm every 50 nanoTeslas (nT). This field was assumed to represent the magnetic anomaly field for the area surveyed (Hernandez et al., 1993). For the analysis of the anomalies, the data was further smoothed to construct a $5 \mathrm{~km}$ regularly spaced grid (Fig. 3(a)).

For an initial analysis, the anomaly map was compared with the surface geology and larger anomalies were correlated to major volcanic features. Three-dimensional representations with various orientations along the trend of the Tepic-Zacoalco rift and other apparent volcanic and topographic lineaments were analyzed for any consistent elongated anomaly trends. Several profiles oriented perpendicular to the regional trend of the rift were also examined to investigate on along- and across-rift spatial changes. In a regional context, the smoothed magnetic anomaly field is characterized by a 'southern' sector within the rift of lowamplitude anomalies, some negative anomalies like those to the north of the Ceboruco and Tepetiltic volcanoes and a 'northern' sector with larger amplitude long wavelength anomalies (Fig. 3(a)). The zero-nT contour allows further subdivision of the rift area, with a central sector within the rift with the low amplitude anomalies north of the Ceboruco and Tepetiltic stratovolcanoes that includes the other major Sanganguey stratovolcano. A central-western sector with high amplitude positive broad anomalies, and a northern 
sector with mainly negative broad anomalies (Fig. 3(a)). The volcan San Juan is characterized by a high amplitude anomaly, whereas the Sanganguey and Tequila volcanoes present smaller amplitude anomalies.

Since our main interest was in mapping the subsurface intrusive and volcanic bodies and any regional structural lineaments, the total field magnetic anomalies were reduced to the pole (Baranov and Naudy, 1964) by using the double integral Fourier method developed by Battacharyya (1965). The reduced to the pole anomaly map results in a simplified pattern of isolated positive and negative anomalies, which show an improved correlation with all major volcanic centers. For the analysis and interpretation of the anomalies, the reduced to the pole anomalies were continued upward at various reference levels by using a $9 \times 9$ operator designed by Mufti (1972). These operations result in smoothing of the anomaly field by the filtering of high frequency anomalies that may be related to shallow sources (Clarke, 1969; Mufti, 1972; Jacobsen, 1987; Neumayer, 1998; Pawlowski, 1995). Fig. 3(b) shows the anomaly field continued upward to one station level ( $5 \mathrm{~km}$ above reference level). The anomaly field is characterized by a pattern of isolated positive and negative anomalies of varying amplitude and wavelengths, and which display a striking correlation with major volcanic units (particularly with the stratovolcanoes), surface geology (the central sector of the rift with the volcanosedimentary sucession and the rock units to the north in the Sierra Madre Occidental), and structural trends (particularly with those associated with the Grande de Santiago river) (Fig. 3(c)). Furthermore, the anomaly map also displays a series of major anomalies which are not correlated with surface bodies and which reflect larger buried sources. In particular, there are two broad high amplitude positive anomalies in the northern sector of the area that lie on either side of the Grande de Santiago river in a zone covered by silicic tuffs and ignimbrites where there is a marked change in the river trend (Figs. 3(b) and (c)). The anomalies possibly correspond to large intrusive bodies of intermediate calc-alkaline composition. The anomaly over the Tepetiltic volcano is elongated to the north over a volcanic terrain that extends in the sector characterized by a smallamplitude minimum in the total field anomaly map.

The reduced to the pole anomalies delinate two major areas that are roughly separated by the zero-nT contour (Fig. 3(b)). The west-northwest sector is characterized by large amplitude positive anomalies, some of them of large wavelengths and with various shapes and orientations (Fig. 3(b)). The southern and eastern sectors are mainly characterized by smaller amplitude negative anomalies, except those positive anomalies over the large stratovolcanoes (Fig. 3(b)). The sector to the north of Ceboruco and Tepetiltic volcanoes is characterized by a series of minima (except a maximum for the Sanganguey volcano), suggesting the absence of major 'magnetized' volcanic and intrusive bodies beneath the Neogene volcano-sedimentary infilling of the rift. The region to the north and northwest is characterized by broad positive and negative anomalies, whose distribution as already mentioned correlates with structural lineaments and in particular with the trend of the Grande de Santiago river. In the central part of the rift there is a distinct trend of the anomalies that coincides with the inferred boundary between the Jalisco block and the Sierra Madre Occidental that lies just north of the Ceboruco and Tepetiltic volcanoes (Fig. 3(b)).

The Grande de Santiago river follows a curse that is closely delineated by the set of concentric anomalies in the northern sector (Fig. 3(b)). The regional structural pattern affecting the thick volcanic sequence of the Sierra Madre Occidental in the area west of the river is characterized by NW-SE normal faults (Aguamilpa area) and a series of anticlines and synclines of the Sierra el Pinabete. In order to quantitatively model the concentric anomalies in the region (Fig. 3(a)), two profiles were selected that cross the major anomalies on either side of the Grande de Santiago river. The Talwani algorithm for 2-D and 2.5-D polygonal bodies has been used for calculating the theoretical anomalies (Talwani, 1965; Plouff, 1976). In the reduced to the pole aeromagnetic map (Fig. 3(b)), the concentric anomaly north of Tepic (profile A-A') occurs over a thick sequence of late Miocene basalts and mafic dikes (Fig. 2(b)). The dipolar anomaly, with a peak amplitude of about $250 \mathrm{nT}$ can be modelled with a thick body extending up to $7 \mathrm{~km}$ depth and a magnetic susceptibility contrast of 0.0035 (Fig. 4(a)). The anomalies to the north along profile $\mathrm{B}-\mathrm{B}^{\prime}$ on either side of the river course (Fig. 3(b)) can be modelled with two deep seated bodies (Fig. 4(b)). The body of the western side of the river is about $10 \mathrm{~km}$ wide and lies at about $1 \mathrm{~km}$ depth. The body on the eastern side of the river is $20 \mathrm{~km}$ wide and lies at about $7.5 \mathrm{~km}$ depth (Fig. 4(b)). The two bodies represent major intrusives of possible granitic composition. The tickness of the two bodies is poorly constrained by the analysis, and in the model depicted in Fig. 4(b) they extend down to a depth of $20 \mathrm{~km}$.

\section{Discussion}

In Fig. 5, we schematically summarize the major lineaments derived from the analysis of the aeromagnetic anomalies and major volcanic and structural lineaments observed or inferred from geologic and structural studies (Figs. 2 and 3). The lineament conecting the Ceboruco and Tepetiltic stratovolcanoes and ending at the San Juan volcano corresponds to that interpreted by Ferrari (1995) as the northern boundary of the Jalisco block (Fig. 2(a)). The continuation of the boundary west of volcan San Juan was not inferred in Ferrari (1995), and in general, the nature and location of the Jalisco block boundary west of the Tepic area and offshore has not been documented (Fig. 2(a)). In models that propose west or northwestward motion of the Jalisco block, the boundary in the Tepic area is inferred to present a similar NW-SE trend (e.g., Luhr et al., 1985; Allan, 1986; Allan et al., 1991). Our analysis of the aeromagnetic anomalies (Fig. 3) suggests a major lineament oriented NE-SW that extends southwest of volcan San Juan towards the Pacific coast and which conects with two other volcanic centers (Fig. 5). The lineament has an approximate orientation $\mathrm{N} 35^{\circ} \mathrm{E}$ and is parallel to a larger lineament, that extends from Punta Mita, at the tip of the peninsula forming the northern limit of the Puerto Vallarta Bay, to the north towards the sharp bend of the Grande de Santiago river, into the area characterized by the large amplitude positive 

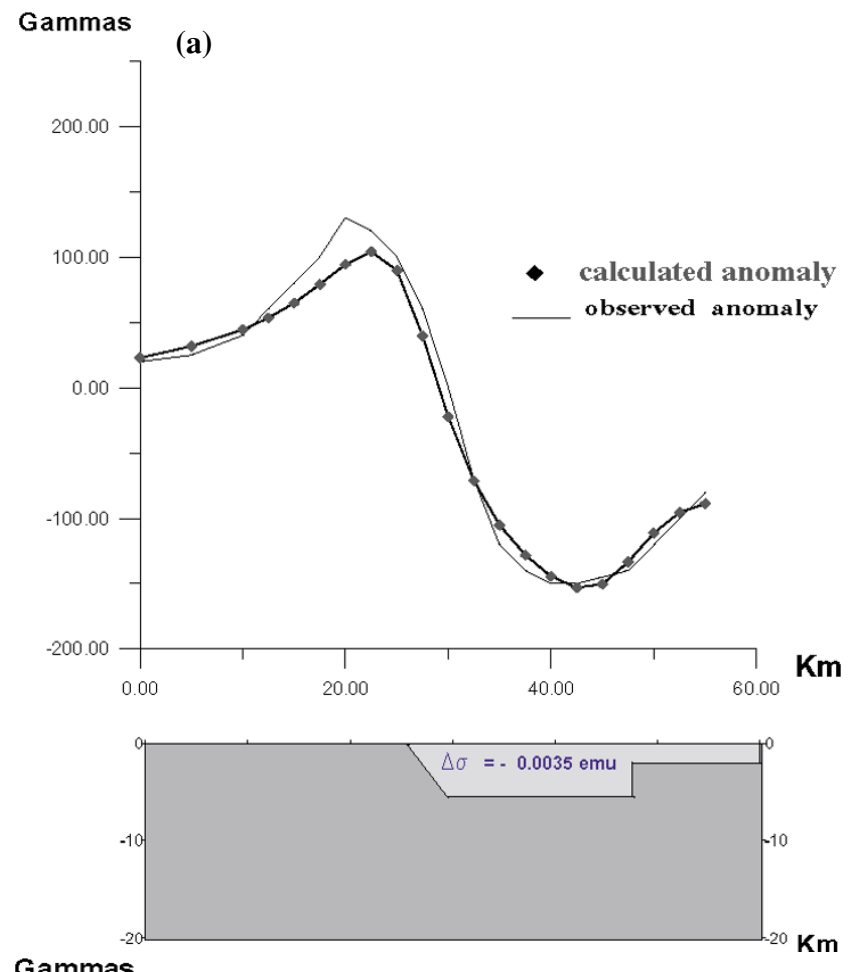

Gammas
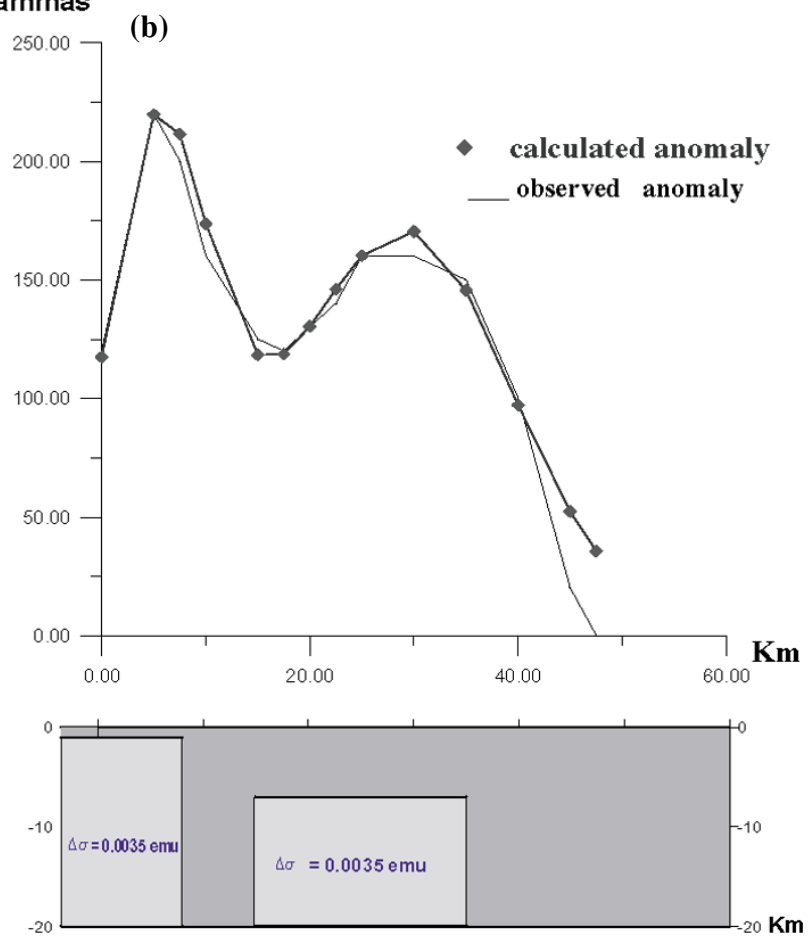

Fig. 4. (a) Magnetic model for profile A-A'(Fig. 3(b)). (b) Magnetic model for profile B-B'(Fig. 3(b)).

magnetic anomalies (Fig. 3(b)). The trend of these lineaments seems to conform with a regional pattern marked by the trend of the western sector of the Ameca graben and the Bahia de Banderas graben offshore. The Ameca graben represents a major structural depression south of the TepicZacoalco rift (Nieto-Obregon et al., 1992). The Ameca graben shows a sharp cusp or change in its orientation from a NW-SE to NE-SW, west of the Amatlan de Cañas volcanic field (Fig. 5). This regional pattern is approximately per-

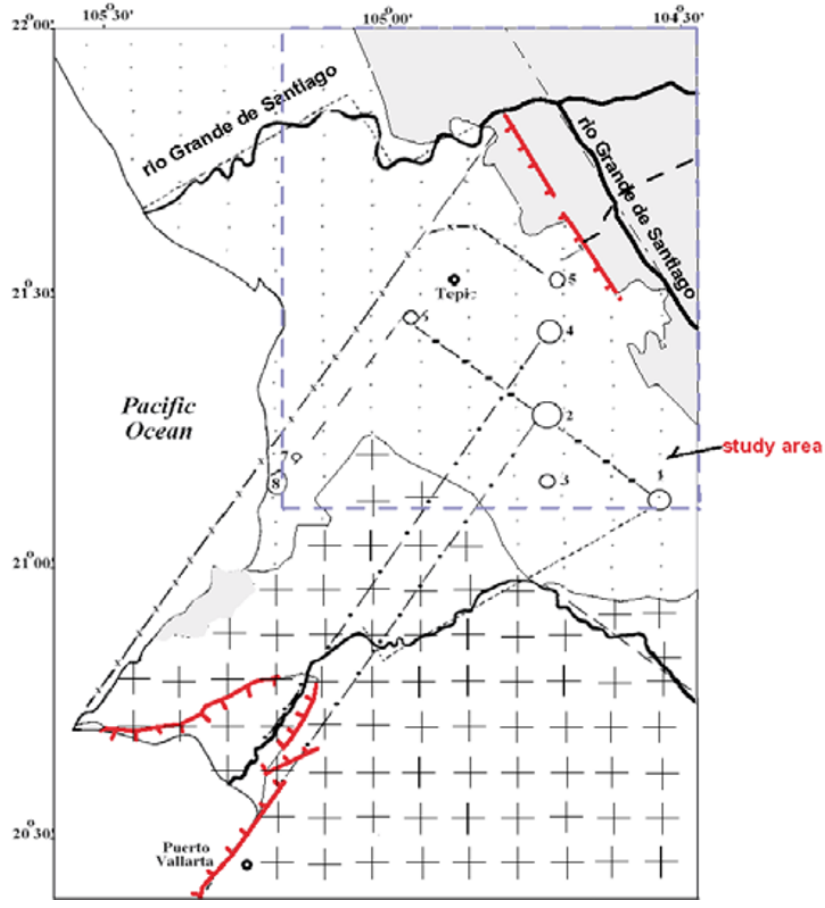

Fig. 5. Schematic representation of major lineaments interpreted from tha analysis of the aeromagnetic anomalies and alignment of volcanic centers for the northern sector of the Tepic-Zacoalco rift. Regional lineaments in the Tepic-Zacoalco rift and Ameca graben (see text for discussion). (A) lineament inferred from analysis of the aeromagnetic anomalies. Note that lineament runs through the San Juan, La Tigra and Ceboruco volcanic centers, and that it is parallel to the regional lineament along the NW end of the Punta Mita peninsula and through the north into the cusp of the Grande de Santiago river. (B) inferred boundary of the Jalisco block by Ferrari (1995). The boundary is expressed by a lineament in the low amplitude negative anomaly area characteristic of the rift volcano-sedimentary Neogene deposits. Note that lineaments $\mathrm{A}$ and $\mathrm{B}$ form an orthogonal pattern parallel to the trend of the western sector of the Ameca graben (wAG) and the Bahia de Banderas graben (BB) offshore. (C) Structural lineament of the western Grande de Santiago river. Note that it conforms an orthogonal pattern oblique to the Tepic-Zacoalco rift pattern formed by A and B. The average orientation of lineament $\mathrm{A}$ is $\mathrm{N} 35^{\circ} \mathrm{E}$, and that for the western Grande de Santiago river is $\mathrm{N} 60^{\circ} \mathrm{E}$. The circles represent major volcanoes ( $1=$ Tequila, $2=$ Ceboruco, $3=$ Cerro Grande San Pedro, 4=Sanganguey, $5=$ Las Navajas, $6=$ San Juan, $7=$ La Tigra, and $8=$ Ceboruco).

pendicular to the inferred trend of the Jalisco block boundary within the Tepic-Zacoalco rift (Ferrari, 1995) that coincides with the volcanic alignment of the Ceboruco, Tepetiltic and San Juan stratovolcanoes (Fig. 5).

To the north, the limit of the Tepic-Zacoalco rift is marked by the Grande de Santiago river that extends from the eastern end of Lake Chapala (southeast of Guadalajara City) to the Pacific Ocean coast (Fig. 2(a)). North of Tepic, the river changes its trend from NW-SE to NE-SW. This western structural lineament has an approximate orientation $\mathrm{N} 60^{\circ} \mathrm{E}$ and is roughly parallel to the trend of the river to the southeast between San Cristobal and the Santa Rosa dam (Fig. 2(a)). It also correlates with the trend of the Ameca graben west of the Amatlan de Cañas volcanic field; however, the trend of the Ameca river to the east does not conform to an orthogonal pattern as seems to be the case in the northern Grande de Santiago area.

The NE-SW structural pattern inferred from the aero- 
magnetic anomalies and the orientation of the western sector of the Ameca graben and Bahia de Banderas graben does not appear consistent with the implied W or NW motion of the Jalisco block. Instead, this structural pattern at the western end of the Tepic-Zacoalco rift seems consistent with dominant extensional tectonics as documented for the Pliocene and Quaternary (Nieto-Obregon et al., 1992; Rosas-Elguera et al., 1996; Ferrari and Rosas-Elguera, 2000; Ferrari, 1995). SW-directed motion of the Jalisco block could explain the formation of the depression of the Tepic-Zacoalco rift SE of the Tepic area. However, actual motion of the Jalisco block may be more complex, as indicated by extension implied by the Ameca graben and the Bahia de Banderas graben and at the Colima graben. Further, the presence of several oblique structural patterns in the Tepic-Zacoalco rift and in the Ameca graben indicates that the deformational and motion history of the Jalisco block has involved different kinematic patterns. Complex kinematic histories have been suggested in previous studies, and episodes of rigth-lateral, left-lateral and extensional deformation have been documented (e.g., Luhr et al., 1985; Nieto-Obregon et al., 1985, 1992; DeMets and Stein, 1990; Michaud et al., 1991; Ferrari, 1995; Rosas-Elguera et al., 1996; DeMets and Traylen, 2000). For instance, Ferrari (1995) has proposed a model for the evolution of the block that involves an episode of left-lateral faulting with ESE motion of the block at about 14-12 Ma, which was followed by an episode of right-lateral faulting and WNW motion of the Jalisco block at about 12-9 Ma.

Acknowledgments. Partial economic support for this project has been provided by the European Community research project. Useful discussions with Luca Ferrari and Jose Rosas-Elguera are gratefully acknowldeged.

\section{References}

Allan, J. F., Geology of the Colima and Zacoalco grabens, SW Mexico: Late Cenozoic rifting in the Mexican volcanic belt, Geological Society of America Bulletin, 97, 473-485, 1986.

Allan, J. F., S. A. Nelson, J. F. Luhr, I. S. E. Carmichael, M. Wopat, and P. J. Wallace, Pliocene-Holocene rifting and associated volcanism in southwest Mexico: An exotic terrane in the making, in The Gulf and Peninsular Province of the California's, edited by J. P. Dauphin and B. R. T. Simmoneit, pp. 425-445, American Association of Petroleum Geologists Memoir, 47, Tulsa, OK, 1991.

Baranov, V. and H. Naudy, Numeric calculations of the formula of reduction to the magnetic pole, Geophysics, 29, 67-79, 1964.

Battacharyya, B. K., Two-dimensional harmonic analysis as a tool for magnetic interpretation, Geophysics, 30, 829-857, 1965.

Clarke, K. G., Optimum second-derivative and downward continuation filters, Geophysics, 34, 424-437, 1969.

DeMets, C. and S. Stein, Present-day kinematics of Rivera plate and implications for tectonics in southwestern Mexico, Journal of Geophysical Research, 95, 21,931-21,948, 1990.

DeMets, C. and S. Traylen, Motion of the Rivera plate since 10 Ma relative to the Pacific and North American plates and the mantle, Tectonophysics, 318, 119-159, 2000.

Ferrari, L., Miocene shearing along the northern boundary of the Jalisco block and the opening of the southern Gulf of California, Geology, 23, 751-754, 1995.

Ferrari, L. and J. Rosas-Elguera, Late Miocene to Quaternary extension at the northern boundary of the Jalisco block, western Mexico: The Tepic-
Zacoalco rift revised, Geological Society of America Special Paper, 334, 41-63, 2000.

Gastil, G., D. Krummenacher, and A. W. Jensky, Reconaissance geologic map of the west-central part of the State of Nayarit, Mexico, Geological Society of America Map and Chart Ser., MC-24, scale 1:200,000, 1978. Hernandez, I., J. Velez, A. Cuevas, and C. Anaya, Hoja Tepic F13-18, Consejo de Recursos Minerales, Aeromagnetic Anomaly Map, scale 1: 250,000, Mexico City, 1993.

Jacobsen H. B., A case for upward continuation as a standard separation filter for potential field maps, Geophysics, 52, 8, 1138-1148, 1987.

Luhr, J. F., S. A. Nelson, J. F. Allan, and I. S. E. Carmichael, Active rifting in southwestern Mexico: Manifestations of an incipient eastward spreading-ridge jump, Geology, 13, 54-57, 1985.

Michaud, F., O. Quintero, E. Barrier, and J. Bourgois, La Frontiere Nord du Bloc Jalisco (Ouest du Mexique): localisation et evolution de $13 \mathrm{Ma}$ à l'actuel, Comptes Rendus Academy Sciences Paris, 312, 1359-1365, 1991

Moore, G., C. Marone, I. S. E. Carmichael, and P. E. Renne, Basaltic volcanism and extension near the intersection of the Sierra Madre volcanic province and the Mexican Volcanic Belt, Geological Society of America Bulletin, 106, 383-394, 1994.

Mufti, R. I., Design of small operators for the continuation of potential field data, Geophysics, 37, 488-506, 1972.

Neumayer, K. H., Shaping filters and the upward continuation problem, Journal of Geodesy, 72, 698-704, 1998.

Nieto-Obregon, J., L. Delgado, and P. E. Damon, Geochronologic, petrologic and structural data related to large morphologic features between the Sierra Madre Occidental and the Mexican Volcanic Belt, Geofisica Internacional, 24, 623-663, 1985.

Nieto-Obregon, J., J. Urrutia Fucugauchi, E. Cabral-Cano, and A. Guzman de la Campa, Listric faulting and continental rifting in western Mexico-A paleomagnetic and structural study, Tectonophysics, 208, 365-376, 1992.

Pawlowski, R. S., Preferential continuation for potential field anomaly enhancement, Geophysics, 60, 390-398, 1995.

Plouff, D., Gravity and magnetic fields of polygonal prisms and application to magnetic terrain corrections, Geophysics, 41, 727-741, 1976.

Righter, K., I. S. E. Carmichael, T. A. Baker, and P. R. Renne, PlioceneQuaternary volcanism and faulting at the intersection of the Gulf of California and the Mexican Volcanic Belt, Geological Society of America Bulletin, 107, 612-626, 1995.

Rosas-Elguera, J. and J. Urrutia-Fucugauchi, Tectonic control of the volcano-sedimentary sequence of the Chapala graben, western Mexico, International Geology Review, 40, 350-362, 1998.

Rosas-Elguera, J., J. Nieto-Obregon and J. Urrutia-Fucugauchi, Ambiente estructural en la frontera norte del bloque Jalisco, in Contribuciones a la tectonica del Occidente de Mexico, edited by L. Delgado-Argote and A. Martin-Barajas, Union Geofisica Mexicana, 1,175-192, 1993.

Rosas-Elguera, J., L. Ferrari, V. H. Garduno, and J. Urrutia-Fucugauchi, The continental boundaries of the Jalisco block and their influence in the Plio-Quaternary kinematics of western Mexico, Geology, 24, 921924, 1996.

Talwani, M., Computation with the help of a digital computer of magnetic anomalies caused by bodies of arbitrary shape, Geophysics, 30, 797$817,1965$.

Urrutia-Fucugauchi, J., Tectonics and volcanism in western-central Mexico: Geophysical studies, EOS (Transactions American Geophysical Union), November Suppl., Fall Meeting, 1993.

Urrutia Fucugauchi, J. and R. Molina-Garza, Gravity modelling of regional crustal and upper mantle structure of the Guerrero terrane-1. Colima graben and southern Sierra Madre Occidental, western Mexico, Geofisica Internacional, 31, 493-507, 1992.

Urrutia-Fucugauchi, J., J. Flores-Ruiz, W. Bandy, and C. MorteraGutierrez, Crustal structure of the Colima rift, western México: gravity models revisited, Geofisica Internacional, 38, 205-216, 1999.

J. Urrutia-Fucugauchi and T. González-Morán (e-mail: tglez@ geofisica.unam.mx) 